\title{
Criticism of Liberals' Call for Freedom of Thought in Ijtihad
}

\section{Kritikan Terhadap Gesaan Golongan Liberal Terhadap Kebebasan Berfikir dalam Ijtihad}

\section{Nur Zainatul Nadra Zainol ${ }^{1,2^{*}}$, Latifah Abd Majid ${ }^{3}$, Faisal Husen Ismail², Arwansyah Kirin ${ }^{2}$}

\author{
${ }^{1}$ Institut Ahli Sunnah wal Jamaah, Universiti Tun Hussein Onn Malaysia, \\ Parit Raja, Batu Pahat, Johor, MALAYSIA \\ ${ }^{2} J a b a t a n$ Pengajian Islam, Pusat Pengajian Umum dan Kokurikulum, \\ Universiti Tun Hussein Onn Malaysia, Parit Raja, Batu Pahat, Johor, MALAYSIA \\ ${ }^{3}$ Fakulti Pengajian Islam, \\ Universiti Kebangsaan Malaysia, Bangi Selangor, MALAYSIA \\ *Corresponding Author
}

DOI: https://doi.org/10.30880/jstard.2020.02.03.010

Received 30 September 2020; Accepted 30 November 2020; Available online 31 December 2020

\begin{abstract}
The main principle of liberalism is to fight for human freedom. They want free and unrestrained people. Moreover, no system of values, laws, and morals can force them to adhere to it including religions, myths, and belief systems brought in a cultural context. This thinking is contrary to the creed of Ahli Sunnah Wal Jamaah. Thus, this article explains the critique of the method of ijtihad of the liberals, namely Nasr Hamid Abu Zayd by presenting an argument to reject this method. The methodology of the study is the analysis of the contents of Nasr Hamid Abu Zayd's book and the findings through descriptive analysis. The results of the study show that liberals support the idea of Human Rights supported by Western society. This idea is contrary to the creed of the Muslim community in Malaysia. Even ijtihad in Islam has certain conditions that must be complied with. The implications of the study show that Muslims need to be wary of accusations and allegations brought by liberals.
\end{abstract}

Keywords: Liberals, freedom of thought, Nasr Hamid Abu Zayd, ijtihad

\begin{abstract}
Abstrak: T Prinsip utama liberalisme adalah memperjuangkan kebebasan manusia. Golongan itu mahu manusia bebas dan tidak dikongkong. Selain itu, tiada sistem nilai, undang-undang dan akhlak yang boleh memaksa mereka berpegang termasuklah agama, mitos dan sistem kepercayaan yang dibawa dalam konteks budaya. Pemikiran ini bersalahan dengan aliran Akidah Ahli Sunnah wal Jamaah. Justeru, artikel ini menjelaskan kritikan kaedah ijtihad golongan liberal iaitu Nasr Hamid Abu Zayd dengan mengemukan hujah bagi menolak kaedah ini. Metodologi kajian adalah analisis kandungan buku Nasr hamid Abu Zayd dan dapatan melalui analisis diskriptif. Hasil kajian menunjukkan golongan liberal mendukung gagasan Hak Asasi Manusia yang didukung oleh masyarakat Barat. Gagasan ini bertentangan dengan aliran akidah bagi masyarakat Islam di Malaysia. Malah ijtihad dalam Islam mempunyai syarat-syarat tertentu yang wajib dipatuhi. Implikasi kajian menunjukkan, umat Islam perlu berhatihati dengan tohmahan dan dakwaan yang dibawa oleh golongan liberal.
\end{abstract}

Kata Kunci: Golongan liberal, kebebasan berfikir, Nasr Hamid Abu Zayd, ijtihad 


\section{Pengenalan}

Dalam dunia Islam muncul tokoh-tokoh yang memperjuangkan kebebasan berfikir dan mengeluarkan pandangan dalam isu-isu pemikiran Islam disebabkan mereka mahu memisahkan politik dan agama. Antara yang lantang dengan ideologi kebebasan berfikir adalah cAli cAbd al-Raziq (1980) yang menyatakan hukum syarak bukan hukum yang tetap tetapi termasuk dalam hukum-hukum yang boleh menerima perubahan selari perubahan zaman dan tempat. Malah Qasim Amin dalam Muhammad cImarah (1976) menggesa kepada kebebasan berfikir sehingga dibolehkan untuk mengkritik pendapat ulama yang muktabar. Kecenderungan sesetengah kelompok yang terpengaruh dengan aliran Islam Liberal misalnya untuk membuka pintu ijtihad yang khusus dan tanpa sebarang prasyarat adalah bahaya. Golongan liberal berpegang kepada kebebasan berfikir adalah sebahagian daripada Hak Asasi Manusia. Namun, Abdul Karim Ali et al. (2009) dan Khalif Muammar (2006) menyatakan walaupun Islam menggalakkan kebebasan berfikir dan mengeluarkan pendapat, Islam mengajar umatnya agar menghormati pendapat ilmuwan dan ulama yang menguasai sesuatu kepakaran dalam bidang keilmuan.

\section{Sorotan Karya}

Deklarasi hak asasi Manusia dengan jelas menyatakan tentang kebebasan setiap individu untuk berfikir dan menyatakan pendirian masing-masing. Berdasarkan kepada deklarasi Hak Asasi Manusia ini, lahir pemikir Islam yang menyeru terhadap keterbukaan untuk berfikir dan berijtihad. Malah mereka juga tanpa segan silu mengkritik turath Islam dengan alasan kebebasan. Kebebasan berfikir sehingga berupaya mengkritik hadith-hadith Rasulullah SAW, Fatima Mernissi (1991: 64) berkata al-Quran semakin hilang arah sebagai kitab petunjuk dan hadith yang terhadap dalam sunan al-Bukhari tidak selari dengan syariat Islam. Beliau mengkritik al-Quran dan al-Sunah. Di dalam bukunya Women and Islam, Fatima Mernissi memberikan pengertian misoginis sebagai kebencian terhadap wanita. Manakala istilah misoginis ditakrifkan sebagai lelaki yang membenci wanita (Kamus Dewan Bahasa 2005). Apabila hadith disatukan dengan perkataan misoginis maka ia membawa maksud hadith-hadith yang mendiskriminasikan kaum wanita. Mernissi sangat teruja untuk membongkar pemahaman hadith tersebut seterusnya memberikan tafsir alternatif yang sesuai dengan sebuah negara moden. Mernissi mengkritik al-Imam al-Bukhari dan beberapa sahabat sebagai pendukung al-Bukhari kerana telah memuatkan hadith yang berunsur misoginis dalam kitab Sahih.

Atas landasan kebebasan berfikir, golongan seperti Fatima Mernissi bukan sahaja mengkritik golongan hadith Rasulullah malah mereka turut mengkritik para ulama antaranya Imam al-Shafici, al-Bukhari, al-Tabari, Ibn Kathir. Jamal al-Banna (1984) dalam al-'Awdah Ila al-Qur'ān mengkritik metodologi yang digunakan oleh Ulama Fiqh adalah sangat sempit dan tidak lagi sesuai diamalkan di zaman moden. Oleh yang demikian, taqlid sering diamalkan oleh umat Islam dulu dan bahkan berlarutan sehingga kini. Walaupun fiqh itu adalah buatan manusia dalam memahami al-Quran tetapi dalam pada masa yang sama fiqh adalah sangat dijaga dan dilindungi daripada kelemahan dan kesilapan yang mana ini adalah sebahagian daripada sifat manusia (Kemal A. Faruqi 2003: 81). Manakala isu taqlid yang sentiasa dicanangkan oleh golongan seangkatan Jamal al-Banna.

Kemal A. Faruqi (2003) mengatakan taqlid dari sudut fiqh bukan sekadar satu perilaku yang hanya mengikut apa yang telah ditetapkan oleh ulama fiqh terdahulu. Tetapi ia adalah keyakinan yang timbul berasaskan kepada ijtihad yang berlandaskan serta kesepakatan melalui ijma' ulama-ulama yang muktabar di sisi Islam. Sebagaimana yang kita ketahui ijma' peranannya adalah untuk melindungi dari sebarang kesalahan pengeluaran hukum. Taqlid bukan sahaja memperakui hukum yang dikeluarkan tetapi apa yang penting adalah keyakinan yang tinggi terhadap ulama-'ulama fiqh yang berada di belakang semua ini, (Kemal A.Faruqi 2003: 89-90)

Sementara Irshad Manji (2000: 13) turut mengagungkan kebebasan untuk berijtihad. Malah beliau menyeru kepada ijtihad bebas dan menolak ijmac. Manji menobatkan dirinya sebagai "mujtahid". Bahkan Manji berbangga dengan anugerah Chutzpah Award oleh Oprah Winfrey yang bererti keberanian yang hampir mencapai tahap gila. Malangnya, beliau tidak pernah mengemukakan definisi ijtihad yang dimaksudkan dalam bukunya. Dia hanya mengemukakan maksud ijtihad dari pemerhatiannya iaitu berfikir dan berbeza pendapat. Manji tidak mengemukakan bentuk subjek yang ingin diijtihadkan adakah ia teks-teks al-Quran atau hadith-hadith Rasulullah SAW.

\section{Metodologi}

Kajian ini berbentuk kualitatif yang melibatkan kajian kepustakaan. Metode yang digunakan ialah analisis kandungan yang terdiri daripada artikel, buku dan wacana. Maklumat latar belakang tokoh yang dikaji diperolehi terus daripada karya bibliografi Abu Zayd yang berjudul Voice an Exile: Reflection on Islam dan sumber sekunder yang terdiri daripada kajian-kajian lepas tentang Abu Zayd dan pemikirannya. Selain itu, untuk kesahan data, penulis telah menjalankan temubual separa struktur dengan ahli akademik untuk mendapatkan pandangan mereka tentang pemikiran Abu Zayd. Manakala analisis data menggunakan kaedah diskriptif dan perbandingan berterusan. 


\title{
4. Dapatan dan Perbincangan
}

\section{Analisis Pemikiran Abu Zayd tentang Kebebasan Berfikir dan Berijtihad}

Kebebasan berfikir dalam rangka membentuk masyarakat yang adil. Setiap individu mempunyai hak dalam melontarkan idea dengan bebas untuk menulis buah fikiran masing-masing (Abu Zayd \& Esther 2004: 257). Sekiranya kita diperintah untuk berperang, maka tidak bermakna kita perlu patuh kepada arahan tersebut kerana Islam membina masyarakat bukan berasaskan kepada suku kaum tertentu (Abu Zayd 2004: 257). Islam Badwi penghalang kepada proses untuk berfikir (Abu Zayd 2004: 224).

Jelas Abu Zayd sebab berlakunya pembekuan pintu ijtihad kerana institusi pendidikan tidak berfungsi sebagai tempat untuk pelontaran idea dalam mencipta ilmu pengetahuan yang baru. Tambah beliau berfikir merupakan proses untuk menggali idea baru telah dinafikan. Dalam dunia Islam, berfikir merupakan satu kerja kerana proses ini merupakan asas kepada kemakmuran. Oleh itu, Abu Zayd menggalakkan kepada penggalian teori-teori baru dalam teks al-Quran bukan hanya bergantung kepada turath Islam seperti yang dilakukan oleh ulama silam (Abu Zayd 2004: 225).

Kebebasan yang telah dianjurkan Abu Zayd sehingga berupaya mengkritik institusi-institusi Islam seperti mengkritik pemikiran ulama antaranya Imam al-Syafici dan al-Ghazali. Pemikiran Abu Zayd adalah membongkar konsep keyakinan kerana beliau percaya banyak teks yang hanya diyakini tanpa upaya pemahaman yang konkrit. Maka dalam buku Imam al-Shafici wa Ta'sis al-Idologiyyah al-Wasatiyyah, Abu Zayd telah mengkritik bahawa pemikiran Imam al-Syafici kerana beliau berpendapat pemikiran Imam al-Shafici telah mendorong kepada masalah keimanan tanpa landasan. Tambah Abu Zayd, Imam al-Shafici telah menempatkan budaya Quraisy sebagai asas dalam pentafsiran al-Quran. Lantas beliau menyelar Imam al-Syafici kerana telah membakukan model pentafsiran al-Quran, teori alSunnah sebagai sumber tasyric ${ }^{c}$ yang autoriti dan memperluas al-Sunah dan Ijmac, tetapi Imam al-Syafici menolak qiyas. Akibat daripada pemikiran Imam al-Shafici ini, kita tidak dapat membezakan sumber teks primer dan sekunder. Ini menunjukkan watak wasatiyyah Imam al-Shafici kerana hanya bersandarkannya kepada sosiologi pemikiran masyarakat Arab Quraish.

Pandangan di atas yang membuat Abu Zayd percaya al-Quran sebagai produk budaya hanya kerana al-Quran menggunakan bahasa manusia dan disampaikan untuk kepentingan umat manusia, juga melihat kepada faktor Asbab alNuzul, ayat-ayat al-Makkiyah dan al-Madaniyyah, nasikh dan mansukh adalah menjadi bukti "campur tangan" sosialpolitik dan sejarah budaya Arab terhadap wahyu Ilahi.

Pemikiran Abu Zayd pebenarnya ini bukan pandangan yang luar biasa kerana pemikiran golongan Mu'tazilah juga berpendapat al-Quran adalah makhluk muhdath; iaitu makhluk yang diciptakan dalil mereka firman Allah merupakan produk daripada salah satu sifat Allah yang Maha Berbicara. Pendapat ini bertentangan dengan golongan Hanbaliyyah dan Ashacriyah yang yakin al-Quran wujud bersamaan (co-exist) dengan Allah, dan tidak ada yang awal dan akhir. Namun, Abu Zayd tetap konsisten dengan pemikiran bahawa al-Quran adalah muhdath. Perdebatan Abu-Zayd untuk menyokong pendapat beliau ini diteruskan dalam kajian yang berjudul al-Tafkir fi zaman al-Takfir. Beliau melontarkan pandangan tentang kepentingan kajian untuk menerokai ilmu baru tentang al-Quran;

\begin{abstract}
"Ilmu, tidak akan memberikan kepadamu sebahagian dirinya, kecuali kamu menyerahkan seluruh dirimu kepadanya. Jika kamu telah menyerahkan kepadanya seluruh dirimu, maka dengan pemberian dirinya kepadamu yang sebahagian itu saja, ia sungguh-sungguh menempatkan kamu dalam bahaya".
\end{abstract}

Abu Zayd menyokong reformasi pemikiran yang telah dilakukan Muhammad ${ }^{\mathrm{c}}$ Abduh iaitu dengan berusaha untuk seimbangkan antara tradisi dengan moden. Kelahiran pemikir moden seperti Kamal Atartuk adalah disebabkan oleh reformasi pemikiran. Namun, institusi pendidikan seperti Universiti al-Azhar gagal memainkan peranan penting dalam melakukan reformasi ilmu Islam. Malah Abu Zayd menegaskan Universiti Al-Azhar menjadi beku disebabkan tiada pemikiran baru yang dapat dilahirkan universiti sepatutnya menjadi medan melahirkan pemikiran baru dan pengembangan pemikiran (Nur Zainatul Nadra et. al, 2014).

\section{Kritikan Kebebasan Berfikir Dan Berijtihad}

Abu Zayd telah menggesa untuk membuka pintu ijtihad kerana beliau beranggapan pemikiran Islam telah beku akibat penetapan kaedah yang telah dilakukan oleh ulama silam seperti Imam al-Shafici. Malah beliau secara terang telah mengkritik Imam al-Shafici dalam bukunya yang berjudul Imam al-Shafici wa Ta'sis al-Idologiyyah alWasatiyyah. Sebelum menjawab gesaan Abu Zayd untuk memberi kebebasan untuk befikir dan dakwaan pintu ijtihad telah tertutup, kajian ini membawa perbincangan ringkas tentang maksud ijtihad dalam Islam. al-'Amidi (t.th, 4: 162) mendefinisikan ijtihad sebagai mencurahkan semua kemampuan untuk mengeluarkan hukum syarak yang bersifat zanni, sehingga merasakan dirinya tidak berupaya untuk berusaha lebih daripada kemampuannya itu. Al-Zuhayli (1986: 1038) pula mendefinisikan ijtihad sebagai proses mengeluarkan hukum-hukum syarak daripada dalil-dalil tafsili dalam syariat. Berdasarkan definisi ini, dapat disimpulkan bahawa ijtihad itu adalah usaha yang dibuat oleh seseorang yang berkelayakan untuk mengeluarkan sesuatu hukum dengan bersungguh-sungguh sehingga tidak mampu lagi berbuat lebih daripada itu. 


\section{Dakwaan Pintu Ijtihad Telah Ditutup}

Dakwaan Abu Zayd tentang ruang ijtihad dalam telah ditutup oleh ulama silam sehingga menjadikan pemikiran umat Islam kini jumud dan beku adalah dakwaan yang salah. Dalam Islam, hukum berijtihad adalah diharuskan. Selain sumber hukum daripada al-Quran dan al-Sunah, ijma ${ }^{\mathrm{c}}$ dan qiyas merupakan sumber rukujan yang digunakan dalam Islam. Malah ijma ${ }^{c}$ dan qiyas merupakan saluran untuk menetapkan hukum bagi hukum yang tidak disebut dalam nas al-Quran atau al-Sunnah. Kedua-dua sumber hukum tesebut merupakan hukum yang dikeluarkan selepas ulama melakukan ijtihad. Dalil tentang harus berijtihad sebagaimana firman Allah SWT:

Maksudnya:

"Maka insaflah dan ambilah pelajaran (dari peristiwa itu) wahai orang-orang yang berakal fikiran serta celik mata hatinya".

Kebenaran untuk melakukan ijtihad telah dibenarkan oleh Rasulullah SAW seperti yang terdapat pada hadith berikut:

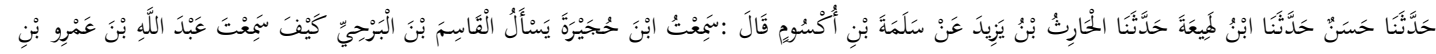

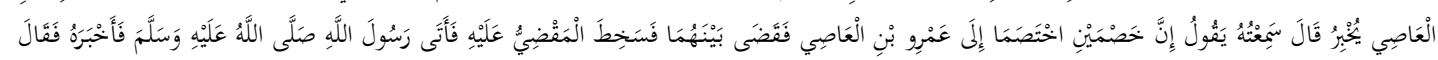

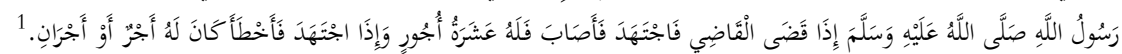

Maksudnya:

Telah menceritakan kepada kami Hasan, telah menceritakan kepada kami Ibn Lahicah, telah menceritakan kepada kami al-Harith bin Yazid daripada Salamah bin 'Uksum telah berkata: Aku telah mendengar Hujayrah bertanya al-Qasim bin al-Barhiyyi bagaimana engkau telah mendengar ${ }^{\mathrm{c} A b d u l l a h}$ bin ${ }^{\mathrm{c}} \mathrm{Amru}$ bin al- ${ }^{\mathrm{c}} \mathrm{As}$ dikhabarkan bahawa Rasulullah SAW telah bersabda: Apabila seseorang hakim menjatuhkan hukuman lalu ia berijtihad dan didapati yang ia ijtihadkan itu benar, maka ia mendapat dua pahala, sekiranya pula ia menjatuhkan hukuman dan berijtihad serta salah, maka ia mendapat satu pahala.

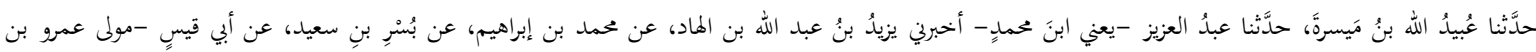

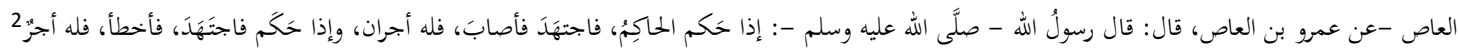

Maksudnya:

Telah diceritakan ${ }^{\mathrm{c}}$ Ubayid bin Maisarah, telah dikhabarkan kepada kami ${ }^{\mathrm{c}} \mathrm{Abd}$ al- ${ }^{\mathrm{c}}$ Aziz bin Muhammad, daripada Yazid bin ${ }^{\mathrm{c}}$ Abdullah bin Usamah bin al-Had, daripada Muhammad bin Ibrahim, daripada Busr bin Sacid, daripada Abu Qays, penjaga ${ }^{\mathrm{c}}$ Amru bin al- ${ }^{\mathrm{c}} \mathrm{As}$, daripada ${ }^{\mathrm{c}}$ Amru bin al- ${ }^{\mathrm{c}} \mathrm{As}$ sesungguhnya Rasulullah Saw telah bersabda: Jika telah menghukum seorang pemerintah maka dia telah berijtihad kemudian tepat maka baginya dua ganjaran, dan sekiranya dia menghukum lalu berijtihad kemudian ia tidak tepat maka baginya satu ganjaran.

Oleh itu, dakwaan Abu Zayd (1997) pintu ijtihad telah ditutup adalah tidak benar, malah ia bertentang dengan dalil al-Quran dan al-Sunah. Para ulama silam seperti Imam al-Shafici bukan penyebab kepada pembekuan ijtihad, malah mereka berusaha bersungguh-sungguh meletakkan kaedah untuk memudahkan generasi akan datang memahami syariat Islam. Al-Zuhayli (2003) ijtihad merupakan satu alat dan mekanisme utama dalam ilmu usul al-fiqh. Isu ijtihad ini telah banyak diperbahaskan oleh para ulama dahulu. Namun begitu, ulama-ulama kontemporari juga tidak kurang hebatnya dalam perbahasan ini khasnya berkaitan dengan keharusan berijtihad pada zaman kini dan hubungannya dengan permasalahan semasa

Al-Zuhayli (2003) menyatakan pada zaman kini, ijtihad merupakan satu keperluan yang mendesak. Hal ini kerana kepelbagaian kegiatan ekonomi dan peristiwa-peristiwa baru ini memerlukan kepada penyelesaian yang sesuai menurut syarak. Oleh sebab itu, para mujtahid moden haruslah memainkan peranan secara bersungguh-sungguh dalam usaha mengeluarkan hukum kepada masalah-masalah baru yang timbul. Keperluan kepada penetapan hukum bagi menjawab persoalan semasa dalam masyarakat Islam hari ini sangat mendesak. Dalam dunia moden dengan segala kemajuannya, baik dari segi ekonomi, sosial mahupun sains dan teknologi, hampir semua perkara dalam kehidupan moden sekarang

${ }^{1}$ Ahmad, Abu Abdillah Ahmad ibn Muhammad ibn Hanbal al-Shaybani. Musnad Ahmad. Kitab al-Mukaththirin nin alSahabah-iza qada al-qadiy fa ijtahid fa asaha falahu saharah ujur. Hadith no. 6716

${ }^{2}$ Abu Daud (10, 5: 428) dalam bab al-qadi yuqti', no. hadith 3574. Al-'Ana'ut menhukumkan hadith ini sahih; Ahmad bin Hambal $(1995,6: 293)$ 
ini telah berubah. Oleh yang demikian, ijtihad semasa adalah amat diperlukan bagi menjawab segala persoalan hukum yang berlaku masa kini.

Menurut al-Qaradawi (1988: 150) jenis ijtihad pada zaman kini boleh dibahagikan kepada dua iaitu ijtihad intiqa' $i$ dan ijtihad al-insha' $i$ :

i. $\quad$ Ijtihad intiqa'i membawa maksud memilih salah satu pendapat yang paling kuat di antara pendapat-pendapat yang ada dalam fatwa atau keputusan hukum yang ditinggalkan ulama terdahulu. Ijtihad ini bertujuan untuk membandingkan di antara pendapat-pendapat yang sedia ada. Dalam usaha itu, mujtahid kontemporari perlu meneliti kembali dalil-dalil yang dijadikan sandaran pendapat tersebut dan akhirnya mampu memilih pendapat yang dianggap paling kuat dalil dan hujahnya. Contohnya pembunuhan yang dilakukan oleh seseorang yang dipaksa dengan ancaman terhadap nyawanya. Persoalannya, siapakah yang akan dikenakan hukuman qisas? Pendapat pertama mengatakan qisas dikenakan kepada si pembunuh kerana dia yang telah membunuh mangsa.Pendapat kedua pula berpendapat bahawa qisas dikenakan ke atas orang yang memaksa pembunuh untuk membunuh kerana dia telah mengancam nyawa pembunuh untuk dijadikan alat bagi membunuh mangsa. Manakala pendapat ketiga menyatakan bahawa qisas dikenakan ke atas kedua-duanya kerana si pembunuh adalah orang yang membunuh mangsa dan si pengugut atau pemaksa telah memaksa pembunuh untuk membunuh mangsa dengan ancaman nyawa pembunuh. Pendapat keempat mengatakan bahawa qisas tidak dikenakan kepada kedua-duanya kerana tidak mempunyai syarat yang cukup untuk disabitkan hukuman ke atas mereka. Jadi, seorang ahli fiqh kontemporari seharusnya memilih pendapat yang paling kuat antara semua pendapat yang ada (Al-Qaradawi 1988: 151-152).

ii. Ijtihad al-Insha' $i$ membawa maksud satu hukum atau keputusan yang dikeluarkan kepada satu permasalahan baru ataupun lama yang belum ditetapkan hukumnya oleh ulama-ulama terdahulu. Contohnya pendapat golongan ulama abad ini yang mewajibkan zakat ke atas hasil sewaan gedung-gedung yang disewakan. Ini adalah pendapat Shaykh Muhammad Abu Zuhrah, ${ }^{\mathrm{c}} \mathrm{Abd}$ al-Wahab Khallaf dan ${ }^{\mathrm{c}} \mathrm{Abd}$ al-Rahman Hasan. Yusuf al-Qaradawi berpendapat, pendapat ini dianggap paling kuat dan beliau telah menguatkan pendapat ini dengan dalil-dalil dalam kitabnya Fiqh Zakat (al-Qaradawi 1988 : 169-172 ).

\section{Kebebasan dalam Melakukan Ijtihad dan Berfikir}

Abu Zayd berkehendak kepada pembukaan ruang untuk berijtihad tanpa ada syarat dan had adalah tidak diterima kerana proses ijtihad hanya berlaku kepada para mujtahid yang benar-benar menguasai ilmu berijtihat. Bahkan ijtihad tidak berlaku kepada hukum-hukum yang telah disabitkan dengan nas qatci tidak boleh ditafsirkan semula walau pun berdasarkan kepada situasi semasa kerana hukumnya telah tetap dan tidak berubah mengikut zaman. Gesaan ini ditolak kerana al-Qaradawi (2005) menyatakan ijtihad hanya berlaku kepada perkara yang tiada nas dalam al-Quran atau alSunnah.

Tidak menjadi kesalahan untuk mengkaji semula kitab turath dengan pelbagai tujuan antaranya mengkaji tentang hadith-hadith yang digunakan ulama untuk menyemak semula kesahihan hadith tersebut. Menurut Yusuf al-Qaradawi (2005: 44) kita harus mengkaji sanad dalam kitab turath untuk mengetahui kesahihannya lantaran tidak semua yang dinisbahkan kepada para salaf adalah benar. Beliau memberi penekanan:

"Perlu diketahui bahawa sebahagian besar isi riwayat yang dinisbahkan kepada para salaf tidak benar penyandarannya. Tidak sedikit perkataan, pendapat atau berita tentang mereka yang tidak memiliki sandaran sanad sama sekali atau ia diriwayatkan melalui sandaran sanad yang lemah dan dusta yang dibuat-buat. Dan riwayat seperti ini, wajib ditolak sesuai standard kritik ilmiyyah yang telah ditetapkan oleh para ulama dalam proses penilaian suatu berita atau riwayat".

Oleh itu, mengkaji semula kitab turath dan menilai pandangan ulama silam tidak salah di sisi Islam kerana tidak semua yang terkandung dalam kitab turath perlu diterima bulat-bulat. Bahkan prinsip utamanya tetap sama, iaitu memeriksa semula kandungan sanad yang terdapat dalam kitab turath tersebut. Justeru, sesuatu hadith atau kisah belum boleh menjadi sandaran yang sahih hanya kerana ia terdapat dalam kitab-kitab turath.

Sementara al-Qaradawi (t.th, 82-83) menegaskan bahawa idea untuk melakukan ijtihad pada nas qat $i$ jelas batil dan ditolak kerana bukan pada tempatnya, iaitu ijtihad berlaku pada maslah yang dalilnya bersifat zanni atau masalah yang tiada hukumnya dalam nas. Sekiranya masalah yang telah jelas hukumnya berdasarkan ketetapan nas qat ${ }^{c} i$, maka ia bukan tempat untuk melakukan ijtihad.

Sementara buku Abu Zayd (1997) yang mengkritik Imam al-Shafici telah ditangkis oleh Sabur al-Shahin dan Muhammad 'Imarah. Mereka menolak karya Abu Zayd yang berjudul Imam al-Shafici wa Ta'sis al-Idologiyyah alWasatiyyah. Muhammad 'Imarah ketika menilai karya Abu-Zayd ini, beliau telah menjelaskan bahawa karya tersebut merosak kemukjizatan al-Quran dan dengan mengatakan al-Quran bukan diciptakan Allah SWT tetapi merupakan produk budaya Arab bagi masyarakat Arab Quraisy. Pertuduhan yang dilemparkan ke atas al-Quran adalah bertentangan dengan sifat al-Quran yang telah digambarkan dalam al-Quran. Benar bahawa al-Quran diturunkan dalam bahasa Arab, tetapi itu tidak bermaksud al-Quran tidak diyakini sebagai ciptaan Allah. Namun, Abu Zayd percaya al- 
Quran sebagai produk budaya hanya kerana al-Quran menggunakan bahasa manusia dan disampaikan untuk kepentingan umat manusia, juga melihat kepada faktor asbab al-nuzul, ayat-ayat al-Makkiyah dan al-Madaniyyah, nask dan mansukh adalah menjadi bukti "campur tangan" sosial-politik dan sejarah budaya Arab terhadap wahyu Ilahi.

\section{Kesimpulan}

Aliran ini menolak autoriti dalam agama. Mereka menekankan bahawa setiap individu berhak memberikan pendapat dan pandangan tentang apa-apa sahaja permasalahan agama. Pendekatan yang digunakan adalah relativisme iaitu kebenaran adalah relative dan tidak boleh didakwa oleh mana-mana pihak. Bagi gerakan ini, orientalis merupakan autoriti yang lebih kritis serta dapat mengemukakan pendekatan yang lebih rasional dan berlainan. Golongan ini dengan biadapnya telah mencabar kewibawaan para ulama yang berijtihad. Hakikatnya, Islam menetapkan bahawa autoriti di dalam ilmu pengetahuan adalah sangat penting. Islam meletakkan kriteria yang cukup ketat dan teliti dalam menentukan siapa yang layak berijtihad (dikategorikan sebagai ulama) dan menjadi 'guru'. Tanpa kriteria tertentu, penyelewengan terhadap agama sangat mudah berlaku. Bahkan, secara logiknya kita lihat setiap disiplin ilmu ada pihak yang pakar dan berautoriti yang dijadikan rujukan. Maka, begitulah juga soal agama. Disiplin-disiplin ilmu seperti syari'ah, akidah, tafsir, hadith serta ilmu-ilmu lain adalah sangat penting dan memerlukan kepakaran. Ia menuntut tenaga, masa, kapasiti usaha yang tidak kurang hebatnya berbanding seseorang yang menguasai bidang perubatan, fizik, kimia dan lain-lain. Daripada ribuan orang yang berusaha menguasai cabang ilmu tersebut, hanya sebahagian sahaja yang diperakui kepakaran dan berautoriti untuk dijadikan rujukan.

Islam tidak menutup pintu ijtihad, malah ia masih diperlukan sehingga kini bagi mengeluarkan hukum kepada isu yang masih belum ada hukum. Dakwaan Abu Zayd adalah tidak benar kerana ijma ${ }^{\mathrm{c}}$ dan qiyas merupakan proses ijtihad. Beliau menggesa kebebasan untuk berijtihad hanya kepada perkara yang tidak melibatkan hukum. Jika sekiranya melibatkan hukum yang belum wujud, maka proses ijtihad hanya boleh dilakukan oleh ulama yang memiliki syaratsyarat yang ditetapkan. Ijtihad ini dilihat sebagai satu alat kepada keanjalan agama Islam. Hal ini bererti hukum Islam tidak kaku, sebaliknya ia sentiasa diperlukan untuk meraikan keadaan masa kini. Keadaan yang akan sentiasa berubah disebabkan kemajuan teknologi yang pesat, masih sentiasa memerlukan kepada hukum-hukum yang dapat memberi penyelesaian kepada permasalahan-permasalahan baru yang timbul. Ijtihad ini dilihat sebagai satu alat hukum yang dapat memberi kemudahan dan kesenangan untuk umat Islam.

\section{Penghargaan}

Penulis ingin mengucapkan terima kasih kepada Universiti Tun Hussein Onn Malaysia, Batu Pahat, Malaysia atas bantuan dan maklumat yang diberikan untuk memastikan kejayaan kajian ini.

\section{Rujukan}

[1] Abd al-Raziq, Ali. (1980). Al-Islam wa al-Usul al-Hukm, Cairo, Dar al-Ma'arif

[2] Abu Zayd, N. H. (1997). Imam Syafi'i; Moderatisme, Eklektisisme, Arabisme. LKIS PELANGI AKSARA

[3] Abu Zayd, N. H., \& Nelson, E. R. (2004). Voice of an exile: Reflections on Islam. Greenwood Publishing Group

[4] Ahmad, Abu Abdillah Ahmad ibn Muhammad ibn Hanbal al-Shaybani (1995). Musnad Ahmad

[5] Daud, A. (2010). Sunan Abu Daud. Dar Ul-Kutub Al-Ilmiyyat

[6] Ali, A. K., \& Nor, M. R. M. (2009). Islam Liberal Isu dan Cabaran. Selangor: Persatuan Ulama' Malaysia

[7] al-Banna, J. (2008). al-Awdah ila al-Qur'an. Kairo: Dar al-Shuruq

[8] Faruqi, Kemal A. (2003).“Pakistan: Islamic Government and Society”, in John L. Esposito (ed.), Islam in Asia: Religion, Politics and Society. New York: Oxford Univerity Press

[9] Mernissi, F. (1991). Women and Islam: An historical and theological enquiry. Basil Blackwell

[10] Muammar, K. (2009). Atas Nama Kebenaran. Universiti Kebangsaan Malaysia: Institut Alam dan Tamadun Melayu

[11] Mohd. Norzi Nasir (2009), "Fatima Mernissi Dalam Timbangan Ilmu Hadith: Analisis Kritik Terhadap Pemikiran dan Dakwaan Hadith-Hadith Misoginis" (Disertasi, Fakulti Pengajian Islam, Universiti Kebangsaan Malaysia)

[12] al-Qaradawi, Y. (1988). al-Fatwa bayna al-Indibat wa al-Tasayyub

[13] al-Qaradawi, Y. (1988). Fiqh al-Zakat: Dirasa Muqarina Li-Ahkamiha Wa-Falsafatiha Fi Dau'al-Qur'an Wa alSunna. Mu'assasat ar-Risala

[14] al-Qaradawi, Y. (2005). al-Siyasah al-Shariyyah fi dau'Nusus al-Shariah wa Maqasidiha. Cairo: Maktabah alWahbah

[15] al-Zuhayli, W. (2003). al-Tafsir al-Munir Fi Al-Aqidah Wa Al-Syari'ah Wa Al-Minhaj. Dar al-Fikir

[16] Zainol, N. Z. N., Abd Majid, L., \& Kadir, M. N. A. (2014). Nasr Hamid Abu Zayd as a Modern Muslim Thinker. International Journal of Islamic Thought, 5, 61 